\title{
Corrigendum: Transfection of small RNAs globally perturbs gene regulation by endogenous microRNAs
}

Aly A Khan, Doron Betel, Martin L Miller, Chris Sander, Christina S Leslie \& Debora S Marks

Nat. Biotechnol. 6, 549-555 (2009); published online 24 May 2009; corrected after print 8 July 2009

In the version of this article initially published, Figure $2 \mathrm{f}$ is not referenced in the figure legend and is referenced as Figure $2 \mathrm{e}$ in the main text. Also, on p.5, right col., para. 1, line 8, miR-21 should be miR-122. The errors have been corrected in the HTML and PDF versions of the article.

\section{Erratum: Venture capital shifts strategies, startups suffer}

Peter Mitchell

Nat. Biotechnol. 27, 103-104 (2009); published online 9 February 2009; corrected after print 8 July 2009

In the version of this article initially published, “GSK Ventures” should have read "GlaxoSmithKline's SR One.” The error has been corrected in the HTML and PDF versions of the article.

\section{Erratum: New relief for gout}

\section{Jill U Adams}

Nat. Biotechnol. 27, 309-311 (2009); published online 7 April 2009; corrected after print 8 July 2009

In the version of this article initially published, the incidence of gout was incorrectly stated to be in the hundreds of millions worldwide and 300 million in the US (p. 309, para. 2). The incidence is known for industrialized countries, not worldwide. In the US, the number is 3 million. The last five lines of the paragraph should have read, "including about 1 in 100 adult men in industrialized countries (an estimated 3 million in the US according to the Centers for Disease Control).” The errors have been corrected in the HTML and PDF versions of the article.

\section{Erratum: Biotech hirings and firings}

Michael Francisco

Nat. Biotechnol. 27, 395, 2009; published online 7 April 2009; corrected after print 8 July 2009

In the version of this article initially published, a company name was omitted from Table 2. GlaxoSmithKline should be listed in third place. The error has been corrected in the HTML and PDF versions of the article.

\section{Erratum: Wyeth preemption case ruling sparks labeling confusion}

\section{Malorye Allison}

Nat. Biotechnol. 27, 399-400 (2009); published online 8 May 2009; corrected after print 8 July 2009

In the version of this article initially published, Phenergan is incorrectly mentioned in paragraph 2 as Merck's antinausea drug. Phenergan is made by Wyeth. The original version also states in paragraph 3 that Wyeth is located in Whitehouse Station, New Jersey. The company's correct location is Madison. The errors have been corrected in the HTML and PDF versions of the article.

\section{Erratum: Academia and the company coin}

Jim Kling

Nat. Biotechnol. 27, 411-414 (2009); published online 8 May 2009; corrected after print 8 July 2009

In the version of this article initially published, on p. 411, left column, last paragraph, one of the researchers" names was incorrectly given as “Martin Feller." It should have read Martin Keller. The error has been corrected in the HTML and PDF versions of the article. 